\title{
プロダクションルール方式によるシーケンス制御の統合的実現法
}

$\begin{array}{lllll}\text { 正 } & \text { 鿓 } & \text { 蔡 } & \text { 以 鋼 } & \text { (神奈川県工業試験所) } \\ \text { 正員 } & \text { 横 } & \text { 井 } & \text { 哲 } & \text { ((株) 椿本チエイン) } \\ \text { 正貝 } & \text { 関 } \square & & \text { 隆 } & \text { (横浜国立大学) }\end{array}$

\section{A Method of Unified Implementation for Sequential Control by Production Rules}

Yigang CAI, Member (Industrial Re search Institute of Kanaga wa Prefe cture),

Satoru YOKOI, Member (Tsubakim oto Chain Co.), and

Takashi SEKIGUCHI, Member (Yokohama National University)

\begin{abstract}
SFC (Sequential Function Chan) is a kind of graphic representations, which is included in IEC standards for sequential control systems. It is introduced as a specific form of PC's (Programmable Controller's) programs. For the simplicity of graphic representations and the clarity of relations of sequences, SFC is much superior to Ladder Diagram that has been so far, widely used in sequential control systems. Each element of SFC is meaningful just by the connections and SFC is strong in the representation of a flow of control sequence. However, SFC has a weak point that it is difficult to describe logic by conditions in detail like interlock relations and to represent intemupt processing. But production rules are obviously suitable for representing logic by conditions and also for interrupting process.

In this paper, we propose a method to translate SFC into production rules, and to implement SFC by production rules using RTPS (Real Time Production System) in which PSL (Production System Language) is used to describe production rules. SFC has three description elements: step representing states in systems, transition representing transition conditions of systems, and link representing the connections between step and transition. We classify the flows of SFC to three types: single sequence, selective sequence and parallel sequence, and, show that each sequence can be described by pairs of transition-step. Conceming a pair of transition-step, a rule for translating the pair of transition-step into production rules is presented. These production rules will be represented by PSL. Finally, we show an example that is implemented by an RTPS.
\end{abstract}

キーワード：シーケンス制御システム，SFC，プロダクションルール，プロダクションシステム

\section{1.はじめに}

シーケンス制御システムの記述法としてSFC (Sequential Function Chart) が広く認知されるようになり ${ }^{(1)-(6)}$, PC (Programmable Controller) の記述言語としても多くのPC機器製 造者により採用されている。ラダーダイアグラム（以下ラ ダーと略す）にない流れ図的表現のわかりやすさや順序関 係の明暸さが評価され，ラダーの次世代の記述言語として 期待されている。しかし，SFCは条件論理やインタロック が表現しにくいので(1), 順序制御以外の制御記述の表現が 困難である。

現在のSFCの処理機能をもつPCは，一般にラダーの処理 もできるため，非順序制御部分はラダーなど他の形式の言 語を用いて記述される。しかし，シーケンス制御のほとん どの場合において，異常処理などを含む非順序制御部分の プログラムの量は順序制御の部分よりもむしろ多い。した
がって，現状ではSFCのみによる記述は不可能である。 これらの問題点に対して，プロダクションルールはちょ うどSFCと正反対の性格をもつ表現形式であり，制御䐓序 は陽に表わせないが，知識はルール単位でまとめられ，運 転モード切り替えや割込処理など非順序制御が簡単にでき る。論理表現の立場からみれば，プロダクションルールは ラダーと同様な表現形式ではあるが, 自然言語により近い ので, ラダーよりわかりやすい。

一方，SFCのほかにもさまざまな表現形式や言語が提案 されている。例えば，同じペトリネットの流れをくむもの としてマークフローグラプ 、C-net ${ }^{(8)}$ とK-NET ${ }^{(9)}$ がある。 また，機械の動作仕様が簡明に表現できる動作線図 ${ }^{(10) や シ ~}$ ーケンス制御の総合支援システムとしてのAPS S $^{(1)}$ な゙もあ る。さらに，ルール型制御のソフトウェアシステムSCD ${ }^{(12)}$

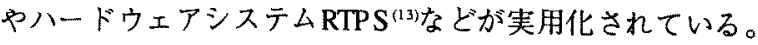
このほかに人工知能によるプログラムの自動生成 ${ }^{(14)}$ 統合 
化システムの構築 ${ }^{(15)}$ な゙の研究開発も行われている。

筆者らは，SFCを基本にした表現形式の一つとしてすで にT-SFC (Total-SFC) を提案してきた ${ }^{(16)(17)}$ 。T-SFCはSFC 部（通常のSFC）、SFCを補助するRFC (Random Function Chart) 部およびインタロックマクロ一覧表より構成 される。RFCはSFCの表現しにくい常時監視などの条件を 記述するためのものであり，インタロックマクロ一覧表は インタロック条件を表わすものである。

本論文では，SFCの記述形式をプロダクションルールに 置き换え，非順序制御部分もプロダクションルールで記述 することによって，一つの言語体系によるシーケンス制御 の統合的実現法を提案する。順序制御の記述自体はSFCが 用いられるので，SFCの良さがそのまま継承される。非順 序制御は論理によって表現されるので，もともとルール表 現そのものである。SFCの流れはすでに単一シーケンス、 選択シーケンス扰び並行シーケンスに分類されているの で(1)，本論文では，それぞれがトランジションーステップ の組によって表現できることを示し，このトランジション ーステップ組の表現をルールに変換する規則を定義する。 さらに，SFCに打けるインタロックに関する時間条件を整 理し，変換されたルールがこの時間条件を満たしているこ とを示す。最後に，プロダクションルールを記述する言語 PSL (Production System Language) によって記述されたプ ログラムを，PCと連結できるプロダクションシステム RTPS (Real Time Production System) 上で実行するシステ ムを構成しその結果について考察する。

\section{SFC}

$<2 \cdot 1>$ SFCの記述要素 SFCの記述要素は図10よ うにステップ、トランジションおよびステップとトランジ ションを連結するリンクの3 種類がある。SFCでシーケン ス制御システムを記述する場合，ステップをシステムのと り得る状態、トランジションを状態遷移に必要な条件、リ ンクをステップとトランジション間の連結と意味付けする ことができる。

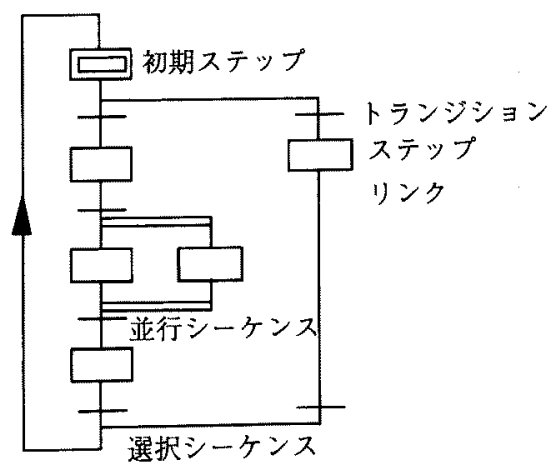

図1 SFC

Fig.1. SFC
シーケンス制御システムは，ある状態で制御を行うが, このことは通常ステップの横につけられるアクションブロ ックによって表現される。IEC規格やJIS規格のSFCにはア クションブロックが使用されている(4)。しかし，アクショ ンブロックはPCの種類によって記述の仕方が異なるし， 他の記述形式への変換も行いにくい。アクションブロック は，SFCの制御流れと比べると不確定要素が多い。市販の 多くのPCは，アクションがラダー形式によって記述され ている。ここでは，1ステップを1アクションとし、ステッ プにはアクションブロックをつけない。したがって、アク ションブロックにおけるアクションが全部SFCの中に陽に 書かれることになり，アクションブロックがSFCから外さ れ，表現は形式上単純になる。

<2・2> 3 種類の基本流れ SFCの流れは基本的に3 種類ある(1。これらを図2に示す。SFCの融り(4)を除けば， どんな複雑なSFCもこの3 種類のシーケンスの組み合わせ と見てよい。

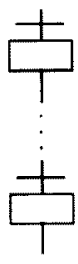

(a)

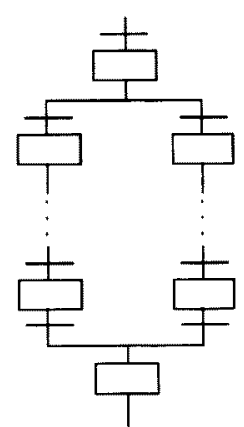

(b)

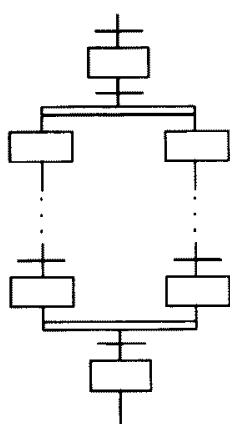

(c)
図2 SFCの3種類のシーケンス

Fig.2. 3 types of sequences in SFC

(a) 単ーシーケンス 単一シーケンスは, 図2(a)が示 すように分岐や合流を含まない単純な処理を表わすもので あり，ステップとトランジションが交互に連なる。SFCは 順序処理を表わす図的表現であるので，全体を細分化すれ ば,この単一シーケンスの組み合わせとみることもできる。

(b) 選択シーケンス 選択シーケンスは, いくつか のシーケンスの中からどれか一つを選択して実行するもの であり，図2(b)のように選択分岐と選択合流に分けられる。 選択分岐のところでトランジションが同時に発火できるも のが複数ある場合は，一般にトランジションの発火順序に 優先順位がつけられる。

(c) 並行シーケンス 並行シーケンスは，複数のシ ーケンスを同時に動かすものであり，図2(c)のように同時 分岥と同時合流に分けられる。

$<2 \cdot 3>$ 非順序制御非順序制御は一般に条件論理と インタロックがあり，規格のSFCはこれらについて明確に 
定めていない。例えば，順序制御の途中での運転モードの 切り替えや異常処理などによる他の制御への移行は条件論 理によって行われ，SFCでは表現できない。また，常時監 視を必要とする運転条件が表現できないので, SFCのトラ ンジションやステップに直接記述されないインタロックの 表現が困難である。このため，条件論理やインタロックを SFCのすバてのトランジションまたはステップにつけ加え ることが提唱されている(4)。現実にはSFCの図的表現の良 さが損なわれるので，SFCと別の場所，いわゆる共通ラダ 一というところで記述するのがもっとも一般的である。

\section{3. プロダクションルールへの变換の準備}

<3・1> トランジションーステップ表現 SFCはトラ ンジションとステップの集合と捉えられる。SFCの知識を 図3のようなトランジションーステップの組の組み合わせ と考える(17),(18)。

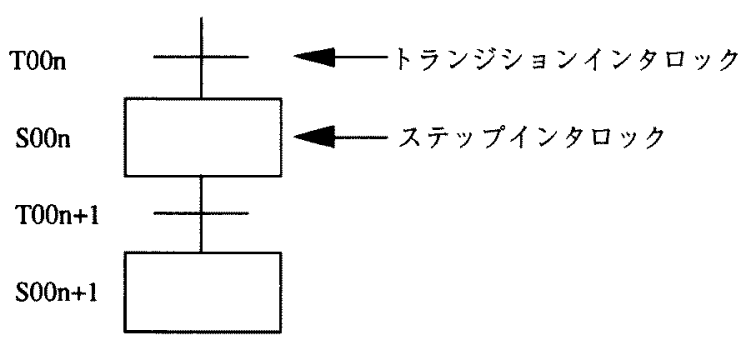

図3トランジションーステップ表現

Fig.3. Representation of transition-step

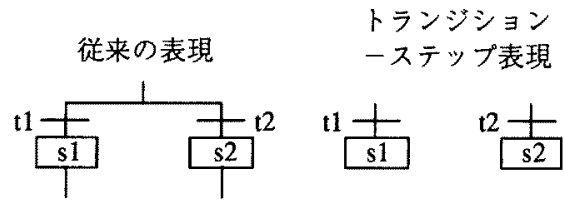

(a) 選択分歧

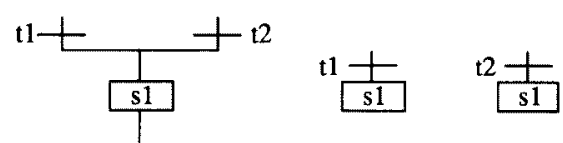

(b) 選択合流

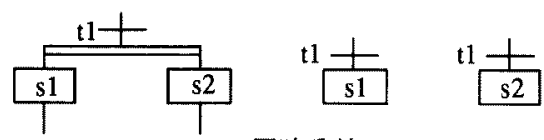

(c) 同時分岐
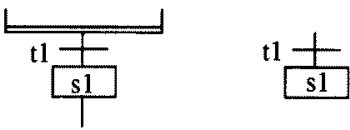

(d) 同時合流

図4 分岐と合流のトランジションーステップ表現

Fig.4. Representations of transition-step about the branching and joining points

もちろん，SFCをステップートランジションの集合とみ ることもできるが，シーケンス制御システムは事象駆動形
の㒕散システムであるので，前ステッフと外部からの入力 信号などの条件によってSFCのステッブ遷移が行われ, 次 のステップが活性となる。トランジションはステップの遷 移条件として表わされ，トランジションの成立でステップ が活性になることにより, トランジションーステップ表現 が適していると考える。さらにSFCのPC走查(スキャン)処 理を考察した結果によれば, トランジションーステップ表 現がPC処理の基本になっていることもわかる ${ }^{(17) 。}$

初期ステップは特別の処理を要するが, 基本的には劦に して何の処理もしないもの上する。単一シーケンスはその ままトランジションーステップ表現に圏き換えられる。選 択シーケンスおよび並行シーケンスは, 分岐と合流のとこ ろについて図4のようにそれぞれを変換すれば，他は単一 シーケンスと同様になる。

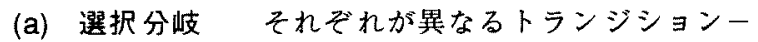
ステップの組に分けられる。シーケンスの塞行においては， どれか一つのトランジションが発火されると，その組だけ が実行される。

(b) 選択合流同一のステップをもつ複数のトラン ジションーステップの組に置き換えられる。どのトランジ ションが発火されても同じステップに入る。

(c) 同時分岐同一のトランジションをもつ複数の トランジションーステップの組に置き換えられる。一つの トランジションの発火によって複数のステップが同時に成 立する。

(d) 同時合流遷移条件は上のステップがすべて成 立していなければならないが, 表現自体は一つのトランジ ションーステップの組となる。

<3・2> インタロックの時間条件 インタロックは共 通のものと個別のものに分けて考える。個別インタロック はさらにトランジションインタロックとステップインタロ ックに分ける (図3参照)。トランジションインタロック はそのトランジションの発火条件として用いられ，次のス テップへの遷移が終われば，インタロックの条件はその時 点でシステムの挙動に影響を与えなくなる。すなお，次 のステップの状態を成立させるために必要で一眭的なもの である。ステップインタロックはステップの状態を維持す るために必要で常時的なものであり, 次のステップに遷移 するまで，システムの挙動に影響を与え続ける。

シーケンス制御におけるインタロックはある時間条件を もち, SFCのステップの歩進はその時間条件のもとで行わ れる。この時間条件は次のように整理できる。

(1) 通常：ステップインタロックが成立している間に T00nが成立すれば，S00nに進む。

(2) 時 間 差：TOOnが成立した後にステップインタロック が成立したとき，S00nに進む。

(3) 非常停止：S00nが成立中にステップインタロックを外 すと，S00nは非活性になる。

(4)安全：S00nが成立中にステップインタロックを外 
し次のT00n+1が成立しても，S00n+1には進 まない。

(5) 再起 動：非常停止後に再びステップインタロックが 成立すると，S00nは活性になる。

SFCをルール表現に変換するとき，以上の5つのインタ ロックの時間条件も満たされる必要がある。

\section{SFCからプロダクションルールへの変換}

<4.1> PSL プロダタションルールは次のIF-THEN 形式で知られ，その集合をルールベースという(19)。

IF 条件/前件部 THEN 結論/後件部

ここで，IF-THENを記速するプログラミング言語として PSLを使用する ${ }^{(20)}$ 。PSLのプログラムは，スタートアップ 文、クラス宣言文およびプロダクション文より構成される。 スタートアップ文は，ブログラムロード時に塞行するモニ タコマンドを記述し，プログラムの初期設定や塞行を行う ものである。クラス宣言文は、ルールのクラス、数拈よび データタイプを定䉝するものである。プロダクション文は， PSLのプロダクションルールを実際に記述するもので，ル 一ル名、前件部および後件部より構成される。(1)式のIFTHENルールはPSLのプロダクション文で次のような形で 表現される。

(p ルール名 前件部 $\rightarrow$ 後件部)

(2)式のルール名、前件部および後件部は使用者によっ て定亲される。

<4・2> RTPS RTPSはPSLにより記述されたプログ ラムを実行するハードウェアであり(13)(20)，图5に示すプロ ダクションルール、作業記憶領域および推論機構より構成 される。推論機構はさらにルールの照合、競合解消および 実行の三つの主な機能をむつ。

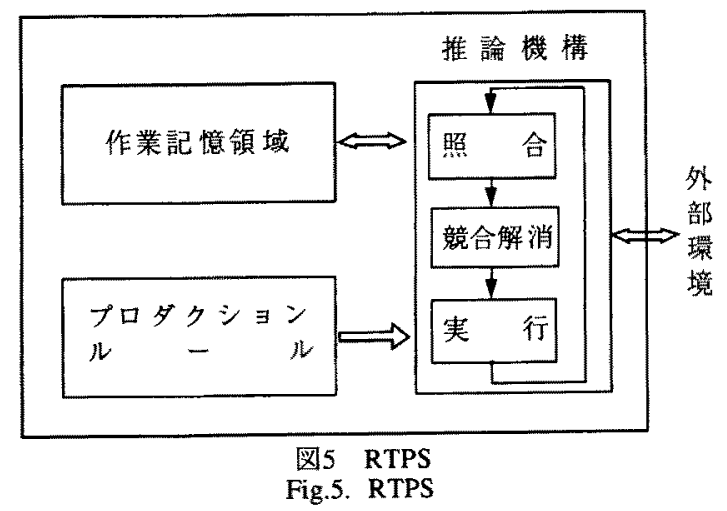

RTPSはインターフェースボートとの接続により，PC98 シリーズのパソコンと接続でき，パソコン環境でのプログ ラムの作成やデバッグやモニタが可能である。RTPSはト ランスピュータ（Inmos社製の32bitCPU）を搭載し, 高速 な推諭が可能である。RTPSはインタフェースユニットを
通してPC (例えば，(株)安川電機製) と接続可能である。 このため, RTPSより直接PCのI/Oへの入出力ができ，PC の代わりに制御装置としての機能をもつ。

$\langle 4 \cdot 3\rangle$ 変换規則图3のトランジションーステップ 表現に扔いて，次の記号を導入する。

To0n：トランジション名

SOOn：ステップ名

F00n:T00nの発火条件

A00n: $\operatorname{s} 00 n$ のクション

X00n：T00nのトランジションインタロック

Yoon: S00nのステップインタロック

く3・1〉ですでに㮏べたようにSFCはトランジションース テップの組によって表わされる。このトランジションース テップ表現がルールに変換できれば，SFCは自ずとルール 形式に変換される。

【定義 変換規則】前述の記号によって表わされる図 3のトランジションーステップ表現を次のT、S、NとRル 一ルに変换する。

T: IF TOOn $\wedge$ SOOn-1 $\wedge$ FoOn $\wedge \mathrm{X0On} \wedge \mathrm{Y} 00 \mathrm{n}$

THEN $\neg$ TOOn $\wedge \neg$ SOOn-1 $\wedge \neg$ XOOn $\wedge$ SOOn

S: IF $\quad$ SOOn $\wedge$ YOOn

THEN AOOn $\wedge$ TOOn+1

N: $\quad$ IF $\quad$ SOOn $\wedge \neg \mathrm{YOOn} \wedge \mathrm{A} 00 \mathrm{n} \wedge \mathrm{T} 00 \mathrm{n}+1$

THEN $\neg$ SOOn $\wedge \neg$ A00n $\wedge \neg$ TOOn+1 $\wedge$ ROOn

R: IF $\quad R 00 \mathrm{n} \wedge \mathrm{Y} 00 \mathrm{n}$

THEN $\neg$ ROOn $\wedge$ SOOn

ただし，ヘはAND，つはNOTを表わす。R00nはルールN が実行されたことを記憶するための条件である。SO0nの ステップインタロッタYOOnがない場合，ルールN拉よびR は必要がなくなる。

$\langle 4 \cdot 4\rangle$ 各シーケンスのルール表現＼cjkstart単ーシーチンス は変換規則によってそのままルール形式の表現となる。選 択シ一ケンスについては，選択分岥と選択合流は図4(a)と (b)のように置き換えたトランジションーステップ表現に ついて変換すればよい。

並行シーケンスについての変換は多少注意を必要とす る。まず図4(c)の同時分岥は一つのTルールによって変換 され，Tの後件部のS00nがs1とs2になり，並行シーケンス の数たけの次ステップ名がここに入る。S、NとRルール はそれぞれのトランジションーステップ表現について変換 を行う。図4(d)の同時合流は一つのトランジションーステ ップ表現のままで変換規則によって変換されるが，Tルー ルの前件部にだけ，並行シーケンスの数だけのt1の前ステ ップ名を入れる必要がある(<5・3>の变換例参照)。

<4.5> インタロックの時間条件の確認 インタロッ クの時間条件については次のように確認できる。 ルールTより, 
(1) 通 常：Y00nが成立している間にT00nが成立すれ ば，S00nに進む。

(2)時間差：T00nが成立した後にY00nが成立すれば, SoOnに進む。

が確認される。プロダクションルールの前件部の各条件の 成立には時間の差による違いがないので, (1)と(2)は同意味 で実現される。ルールSはステップのアクションを実行し 次のステップへの歩進をさせるためのものである。さらに ルールNより,

(3) 非常停止：S00nが成立中にYOOnを外すと, T00n+1に進 まず，S00nが否定され，出力がなくなる。

(4)安 全：S $00 \mathrm{n} か ゙$ 成立中にY00nを外して次のT00n+1が 成立しても，T00n+1が否定され，S00n+1に は進まない。

が確認できる。ルールNがいったん実行されると条件 R00nが記憶され、ルールRが初めて実行可能となり、こ のルールにより, 次が確認できる。

(5)再起動：R00n後に再びY00nが成立すれば, S $00 \mathrm{n} か ゙$ 成 立し, 再起動される。

ルールTはシーケンスの歩進を担当し，ルール $\mathbf{T} 、 \mathbf{N} と \mathbf{R}$ はステップにおけるアクションを出力するための自己保持 に相当する。ルールS、NとRはシーケンス制御の自己保 持という重要な役割をもっており，順序を決めるだけのも のではない。これは今までのSFCの歩進に一般に認識され ていなかったことであり，本記述によってその性質がはっ きりと表わされ，さらに変換されたルールの実行によって 保証される。

<4.6> SFCからPSLへの变換記述例として変換規 則によるPSLの記述を次のように形式的に示す。

(p T00n

\&e (subtask ${ }^{\wedge}$ name T00n)

\&el(active_state ${ }^{\wedge}$ name S0On-1)

\&e2(input ${ }^{\wedge}$ name F00n)

\&e3(input $\wedge^{\wedge}$ name $X 00 n$ )

$\&$ 4(input ${ }^{\wedge}$ name Y0On)

-> (remove \&e \&e 1 \&e3)

(make active_state ${ }^{\wedge}$ name SOOn))

(p s00n

(active_state ${ }^{\wedge}$ name S0On)

(input ^name Y00n)

$\rightarrow \quad$ (A0On)

(make subtask ^name T00 $n+1)$ )

(p) NOOn

$\&$ e(active_state ${ }^{\wedge}$ name $S 00$ n)

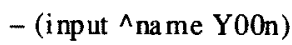

(A00n)

\&e1 (subtask ^name $\mathrm{T} 00 \mathrm{n}+1$ )

--> (remove \&e \&e 1)

$-(\mathrm{A} 00 \mathrm{n})$ (make restart ^name R00n))

(p R00n

\&e(restart ^ name ROOn)

(input ${ }^{\wedge}$ name $\mathrm{YOOn}$ )

$-\rightarrow \quad$ (remove \&e)

(make active_state $\wedge^{\wedge}$ name SOOn))

ここで，\&eは作業記憶領域上の要素を指し，make、 modify、removeはそれぞれ要素の作成、変更、削除のた めの関数である。ルール名は一部の要素名と同じものが使 用されているが，便宜的なむのであり，混乱は生じない。 アクションを表わすA00nだけが制御内容が決ってからで ないと具体的に記述できないものなので,ここでは単に $(\mathrm{A} 00 \mathrm{n})$ と，またその否定を一 $(\mathrm{A} 00 \mathrm{n})$ と記しておいた。

\section{5. 実行例とその効果}

$<5 \cdot 1>$ コンベアの簡単な例 図6はある単純なコン ベアの例の略図およびその操作盤である(17)(18)。

EP(非常停止) PB0(自動運転) PB1(起動) GL1(起動中ランプ)

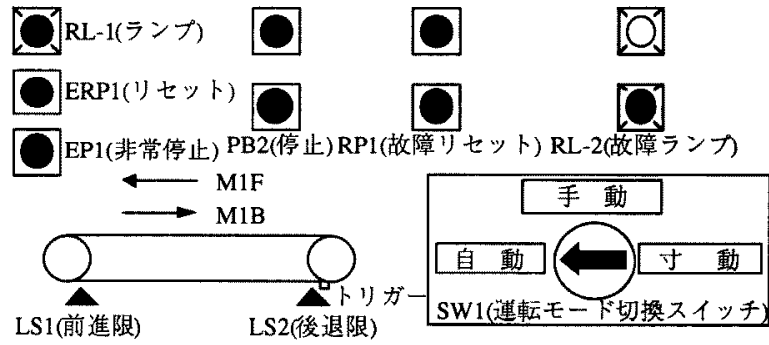

図6 コンベアの例

Fig.6. An example about a conveyor

運転モード切換スイッチSW1によって自動、手動およ び寸動のいずれかの運転モードが選択される。自動運転 PB0を押すと, リミットスイッチLS2がONの状態でコンベ アが前進(M1F)する。コンベア上のトリガーがLS2の位置 からLS1の位置まで移動しLS1がONとなる。LS1がONする とコンベアが5秒停止し, それから逆転して, 後退(M1B) する。トリガーがLS2の位置まで戻るとコンベアが停止す る。次に停止後 5 秒たつと上の動作を繰り返す。異常が起 きた場合は, 非常停止押ボタンEP1を押し, 非常停止表示 ランプRL-1を点灯させる。非常停止りセットボタンERP1 を押してから, 手動操作でコンベアを定位置(LS2がON状 態)まで戻す。故障が起きたときもRP1などにより同様に 処理する。

<5.2>SFCの表現この例の自動運転モードの一部 のSFC部の表現を困7に示す。非順序制御の全表現は文献 (17)，一部の变换例はく5・4>に記述されている。

<5.3> SFC部のPSLへの変換 ここで, 自動運転モ ードのSFCからPSLに変換したいくつかのルールを示す。 
S000は初期ステップであるが，特に処理を要しない。 PCが起動されたら自動的に活性になるものである。次に 示すのはT001-S001を変換したルールである。

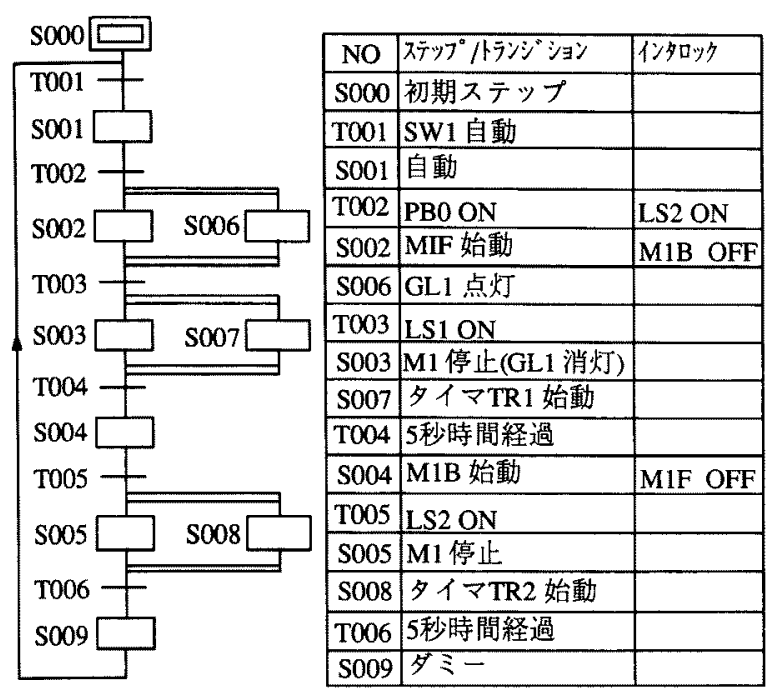

図7自動運転モードのSFC

Fig.7. The SFC of auto mode for Fig.6.

(p T001

\&e(subtask ^name T001)

\&e1(active_state $\wedge$ name $S 000$ )

\&e2(input ${ }^{\wedge}$ name SW lauto)

-> (remove \&e \&e 1 \&e2)

(make active_state ${ }^{\wedge}$ name $\mathrm{S} 001$ )

(make input_old $\wedge^{\wedge}$ ame SW1auto))

(p) S001

(active_state ^name S001)

$\rightarrow \quad$ (write "自動運転絓")

(make subtask ^name To02))

次に並行シーケンスのルール例を示す。T002-S002と T002-S006は並行シーケンスの同時分岐である。

(p $\mathrm{T} 002$

\&e(subtask ${ }^{\wedge}$ name T002)

\&e1(active_state ${ }^{\wedge}$ name S001)

\&e2(input ^name PBOon)

\&e3(input ${ }^{\wedge}$ name LS2on)

\&e4(memory_out ${ }^{\wedge}$ name M1Boff)

-> (remove \&e \&e 1 \&e3)

(make active_state $\wedge^{\wedge}$ name S002)

(make active_state ${ }^{\wedge}$ name S006))

(p $\mathrm{S} 002$

(active_state $\wedge^{\wedge}$ name $\mathrm{S} 002$ )

(memory_out ${ }^{\wedge}$ name M1Boff)

$\rightarrow \quad$ (make output ${ }^{\wedge}$ name M1Fon)

(make subtask $\wedge_{\text {name }}$ T003))

(p) NO02 \&e(active_state $\wedge^{\wedge}$ name S002)

- (memory_out ^name M1Boff)

\&el (output $\wedge^{\wedge}$ name Mi Fon)

\&e2(subtask ^name T003)

-> (remove \&e \&e 1 \&e2)

(make restart ^name R002))

(p R002

\&e(restart ^name R002)

(memory_out $\wedge_{\text {name M1Boff) }}$

$\rightarrow \quad$ (remove \&e)

(make active_state ${ }^{\wedge}$ name $\left.\mathrm{S} 002\right)$ )

(p) S006

(active_state ${ }^{\wedge}$ name $\mathrm{S} 006$ )

--> (make output ${ }^{\wedge}$ name GLlon))

T002-S002とT002-S006のTルールがT002の一つになっ

ている。次はこの同時分跂に対応する同時合流のルール例 である。

(p T003

\&e( subtask ^name T003)

\&el (active_state ${ }^{\wedge}$ name S002)

$\&$ 2(active_state ${ }^{\wedge}$ name S006)

\&e3(input ^ name LS1 on)

-> (remove \&e \&e 1 \&e 2 \&e3)

(make active_sta te ${ }^{\wedge}$ name $\mathrm{S} 007$ )

(make active_state ${ }^{\wedge}$ name S003))

\&e1と\&e2はS002拉よびS006の同時成立を必要とする。

$<5.4>$ 非順序制御のPSLへの変換例非順序制御は 一般にルール形式の知識であるが, 筆者らはT-SFCで表現 することを提唱している。T-SFC表現では，非順序制御を RFCとインタロックマタロ一覧表で表わす。RFCは共通イ ンタロッタ、故障処理、モード切り替えおよび運転/停止

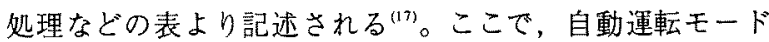
時の故障発生に関するRFCの一部とインタロックマクロー 覧表を表1に示す。表1から故障発生の(1)非常停止の処理に ついて次のルールが得られる。

(p 非常停止 1

(input $\wedge^{\wedge}$ name EPlon)

$\&$ e(active_state $\wedge^{\wedge}$ name $\left.\& n\right)$

-> (remove \&e)

(remove subtask)

(make memory ${ }^{\wedge}$ name $\& n$ ))

(p) 非常停止 2

\&e(input ${ }^{\wedge}$ name EPlon)

- (active_state ${ }^{\wedge}$ name $\left.\& n\right)$

$->\quad$ (remove \&e)

(make output ${ }^{\wedge}$ name RLion) (make output ${ }^{\wedge}$ name M1Foff) (make output ${ }^{\wedge}$ name M1Boff) (make output ^ name GLloff)) 
表1 RFCおよびインタロックマクロ一覧表

Table 1. RFC and Inte rlock table

\begin{tabular}{|c|c|c|c|c|c|}
\hline \multicolumn{6}{|c|}{ 共通インタロックによる動作 } \\
\hline \multirow{2}{*}{ インタロック } & \multirow{2}{*}{ 運転モード } & \multicolumn{3}{|c|}{ 動作するアクチュエータ } & \multirow{2}{*}{ 動作 } \\
\hline & & 種類 & 信号名 & 用 & \\
\hline \multirow{4}{*}{$\begin{array}{l}\text { 故障 } \\
\text { 発生 }\end{array}$} & \multirow{2}{*}{ 自動 } & モー夕 & M1 & コンベア起動用 & 即停止 \\
\hline & & ランプ & GL1 & כ彷ヤ起動中ランプ & 消灯 \\
\hline & 手動 & Eータ & M1 & コンベア起動用 & 即停止 \\
\hline & 寸動 & $\varepsilon-\xi$ & M1 & コンベア起動用 & 即停止 \\
\hline
\end{tabular}

故障(故障発生/故障猃断/安全保証)

\begin{tabular}{|c|c|c|c|c|c|c|c|}
\hline \multirow{2}{*}{$\begin{array}{l}\text { 運転中 } \\
\text { の‡ート }\end{array}$} & \multirow{2}{*}{$\begin{array}{l}\text { 動 } \\
\text { 作 }\end{array}$} & \multirow{2}{*}{ 表示 } & \multirow{2}{*}{$\begin{array}{l}\text { 再起動 } \\
モ ー ト ゙\end{array}$} & \multicolumn{2}{|c|}{ 復旧後操作 } & \multirow{2}{*}{ 表示 } & \multirow{2}{*}{$\begin{array}{l}\text { 再起動 } \\
\text { 動作 }\end{array}$} \\
\hline & & & & 1)»卜 & 再起動 & & \\
\hline \multirow{3}{*}{ 自動 } & \multirow{3}{*}{$\begin{array}{l}\text { 即 } \\
\text { 停 } \\
\text { 止 }\end{array}$} & \multirow{3}{*}{$\mid \begin{array}{c}R L 1 \text { 点灯 } \\
\text { OR } \\
R L 2 \text { 点灯 }\end{array}$} & 自動 & \begin{tabular}{|l|l|} 
ERP1 & \\
OR & RP1
\end{tabular} & PBION & \multirow{3}{*}{$\begin{array}{c}R L 1 \text { 消灯 } \\
\text { OR } \\
R L 2 \text { 2消灯 }\end{array}$} & 再自動 \\
\hline & & & 手動 & \begin{tabular}{|l|l} 
ERPI & \\
$\mathrm{OR}$ & $\mathrm{RPI}$ \\
\end{tabular} & PBION & & 再手動 \\
\hline & & & 寸動 & \begin{tabular}{|ll|l} 
ERP1 & \\
OR & $R P 1$ & $P$ \\
\end{tabular} & PB1ON & & 再寸動 \\
\hline & \multicolumn{2}{|c|}{ マク口名称 } & \multicolumn{2}{|r|}{ 内 容 } & \multicolumn{2}{|c|}{ ON/OFF } & \\
\hline & \multirow{2}{*}{\multicolumn{2}{|c|}{ 故障発生 }} & & 非常停止 & \multicolumn{2}{|r|}{ OFF } & \\
\hline & & & (2) & 過負荷 & \multicolumn{2}{|r|}{ OFF } & \\
\hline & \multicolumn{2}{|r|}{ 故障診断 } & (1) & $\mathrm{LS} 1 * \mathrm{LS} 2$ & \multicolumn{2}{|r|}{$\mathrm{ON}$} & \\
\hline & \multicolumn{2}{|r|}{ 安全保証 } & (1) & $\mathrm{M} 1 \mathrm{~F} * \mathrm{M} 1 \mathrm{~B}$ & \multicolumn{2}{|r|}{ OFF } & \\
\hline & \multirow{2}{*}{\multicolumn{2}{|c|}{ 自動運転 }} & (1) & 起動PB0 & & $\mathrm{N}$ (琚憶) & \\
\hline & & & (2) & 停戈PB2 & & OFF & \\
\hline
\end{tabular}

プロダクション文「非常停止 1」はRTPS内部処理を行 うものであり，故障発生時の動作が即停止に対応する。こ れによってSFCの実行が停止し，止まったステップの番号 が記憶される。「非常停止 2 」は外部への出力であり，す ベて表1の記述によって処理される。この二つのルールが いつも非常停止押しポタンEP1を監視しており，EP1が押 されたら直ちに発火して非常停止処理に入り，SFCの実行 を中止させる。規格のSFCでは，この二つのルールに相当 する内容をSFCのすべてのステップに記述する必要があり たいへん慗雑になる。

RFCとインタロックマクロ一覧表は表の形となっている が, 基本的にはルール表現そのるのである。運転モード切 り替え等も前述非常停止処理の例と同様に，ルールによっ て簡単に記述できる。

く5.5> RTPSによる効果前述の上うに图6のコン ベアのSFCをすべてPSLの記述に変換したものをRTPS上 で実行し，PC上でのSFCの実行結果と同様な挙動が得ら れた。これによって、プロダクションシステムによるSFC の表現および実現が確濏された。RTPSはPCに依存せずに 直接I/O装置へのアクセスができる。つまり，PCの代わり にRTPSがシーケンス制御の制御装置として用い得る。さ らに, 本研究によって次のいくつかの効果が確認され, プ
ロダクションシステムの長所として評価できる。

先ずは、制御プログラムにプロダクションルールという 一貫した記述形式が用いられたことである。ラダーによっ て一貫した記速でシーケンス制御のプログラムが作成でき るが，SFCだけではそれができなかった。たいていのPC は、アクションやインタロックをラダーによって記述する 方式を採っている。ラダーはわかりにくいが，ルール形式 はわかりやすい。しかも，アクションやインタロックは SFCの制御流れと一緒にルール形式に翌換されるので，ラ ダーを意識せずに容易にプログラムの作成ができる。順序 制御の部分はそのままSFCによって記述し，変換規則によ って機械的にルールに变換するので,プログラム制作者は 変換されたプロダクションルールを気にする必要はない。

次には，インタロックの時間条件が本論文で定義した変 換規則によって完全に保証された点である。インタロック はシーケンス制御システムにおける重要な要素の一つであ るが，SFCの中ではその表現方法が明示されていない。こ のため，現有のPCで制御を確実に実行するためには， ダーなどでPC使用者各自が記述しなければならない。そ の形式は決っていないので,特にインタロックに関する「安 全」という時間条件が保証されているかどうかは各PC使 用者のデバッグに委极られる。この時間条件はシーケンス 制御にかかわる専門家がまとめられたもので、シーケンス 制御の専門的知識の一つでもある(17)。

最後には，シータンス制御のよりわかりやすい記述が可 能となったことである。シーケンス制御のプログラムがル ールによって記述することができれば，さらに自然言語に 近い形態の言語によって記述も可能となり, 制御プログラ ムの自動設計や, 設計から制御ブログラムへの一貫したブ ログラミング方法なども考えられる。しかも，故障診断や 割込処理などSFCで表現しにくいが，本来IF-THENルール で表現しやすい知識簡単に制御装置に取り入れられるよ うになった。

\section{6.おわりに}

本論文では，一つの試みとして，SFCの記速をブロダク ションルールの記述に変換する方法を提案し，さらに実行 例によって，PSLで記述したプログラムをプロダクション システムRTPS上で実行し，その動作を確慧した。そして， 変換のためのインタロックの時間条件をまとめ, 変換規則 はこれらを保存してルールに変換することも示した。最後 に，本手法によって得られた効果を述べた。しかし，制御 装監としてRTPSを使う場合には処理速度が問題となる。 特に，照合するルール数が多いとその処理速度が遅くなる 傾向がある。RTPSを並列して対応することも考えられる が(21)，今の段階では安価なPCに勝るものはない。しかし ルールの形加らは知識の抽出や抽象化がやりやすくなるた め，知識の蓄積や学習手法の導入が可能となる。これらを 今後の課題としたい。

(平成 5 年9月 24 日受付) 


\section{文献}

(1)関口など：「シーケンス制御工学」, 電気学会 (1988)

( 2 ) AFCET: LE GRAFCET, ADEPA (1977)

(3)戸塚：「グラフセ (GRAFCET)の概要と応用」, オートメーシ ヨン, 29-5, pp.43-50(1984)

(4)IEC 65A (Secretariat) 67: Draft-Programmable Controller Part 3: Programming Languages, IEC (1987)

(5)関口:「シーケンス制御システムの表現法」, オートメー ション, 32-7, pp.9-14, 日刊工業新聞社 (1987)

(6)笹嶋：「PCブロダラミング言語とSFC」, オートメーショ ン, 32 -7, pp.15-23, 日刊工業新閆社 (1987)

(7) 長谷川：「マークフローグラフ (MFG) によるシーケンス制御 の表現」, オートメーション, 29-5, pp.32-41 (1984)

(8) 蔦田、村田、松本：「ペトリネット拡張の高フレキシブルFA 用言語C-net」，オートメーション, 29-5, pp.51-56 (1984)

(9) Y. Nagao, et al: Petri net based programming system for $F M S$, Proc. IEEE Annual Conference on Industrial Electronics(IECON'90), pp.456-461 (1990)

(10)中尾：「機械の動作仕様を簡明に表現する「動作線図」」, オートメーション, 29-5, pp.63-70 (1984)

(11)保谷：「シーケンス制御統合支援システム(APSシステム)」, オートメーション, $29-5$, pp.71-75 (1984)

(12)田代など：「ルール型制御ソフトウェアシステムSCDの開 発」，情報処理学会論文集，27-5, pp.552-561 (1986)

(13)川辺、西村：「AIコントローラーRTPSとその応用一」, 安川電機, 54-207, pp.237-242 (1991)

(14)中山など：「シーケシス制御ソフトゥエア自動生成システ ムーモテルに基づく設計バラタイムー」, 人工知能学会研 究会資料, SIG-KBS-9003-8, pp.71-79 (1990)

(15)神河など：「三菱統合一元化SEシステム」, 三菱電機技報, 66-4, pp.87-92 (1992)

(16)横井：「マテリアルハンドリング自動制御システム TAMCOS」, TSUBAKI TECHNICAL REVIEW, 2-1, pp. 21-28 (1992)

(17)横井、蔡、関口：「T-SFC-FAシステムの一つの記述法 ーマテハン制御を中心としてー」, 電気学会研究会資料, 産業電力電気応用研究会, IEA-93-1, pp.1-12 (1993)

(18)蔡、関口、横井：「ブロダクションルールによるSFCの実 現法」, 電気学会研究会資料, 産業電力電気応用研究会, IEA-93-2, pp.13-22 (1993)

(19)上野：「知識工学入門」, オーム社 (1985)

(20)「RTPSマニュアル」, (株)安川電機製作所

(21)川辺:「並列プロダクショシシステム」, 第5 回人工知能 学会全国大会論文予稿集, 10-1, p p .429-432 (1991)
蔡以鋼 (正員) 昭和 35 年3月29日生。59年3月山 梨大学工学部計算機科学科卒業。平成3年 3月横浜国立大学大学院工学研究科電子情 報工学専攻博士後期課程修了。同年4月同 大学工学部助手。平成6年4月神奈川県工 業試験所技師, 現在に至る。工学博士。 知識工学、シーケンス制御工学およびペ トリネット理論などの研究に従事。計測 自動制御学会会員。

横井哲 (正員) 昭和11年12月17日生。35年3月

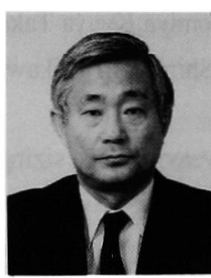
名古屋工業大学工学部機械工学科卒業。 同年 4月(株)椿本チエイン入社。現在, 同社マテハン事業本部技術推進担当次 長。主として, マテリアルハンドリング システム、新システム開発に従事。日本 機械学会会員。

関口 隆 (正員) 昭和 10 年6月11日生。34年横浜

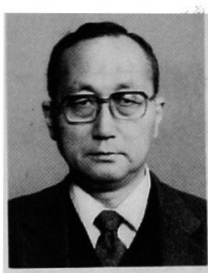
国立大学工学部電気工学科卒業。同年安 川電機(株) 入社, 制御装置の設計に従事。 36 年横浜国立大学工学部助手。講師、助 教授を経て, 現在, 電子情報工学科教授。 工学博士。FA、CIMシステムの研究に従 事。計測自動制御学会、システム制御情 報学会、日本ファジィ学会およびIEEEの 会員。 